\title{
Spatial datasets of radionuclide contamination in the Ukrainian Chernobyl Exclusion Zone
}

\author{
Valery Kashparov $^{1,3}$, Sviatoslav Levchuk ${ }^{1}$, Marina Zhurba ${ }^{1}$, Valentyn Protsak ${ }^{1}$, Yuri Khomutinin ${ }^{1}$, \\ Nicholas A. Beresford ${ }^{2}$, and Jacqueline S. Chaplow ${ }^{2}$ \\ ${ }^{1}$ Ukrainian Institute of Agricultural Radiology of National University of Life and Environmental Sciences of \\ Ukraine, Mashinobudivnykiv str. 7, Chabany, Kiev region, 08162, Ukraine \\ ${ }^{2}$ NERC Centre for Ecology and Hydrology, CEH Lancaster, Lancaster Environment Centre, Library Av., \\ Bailrigg, Lancaster, LA1 4AP, UK \\ ${ }^{3}$ CERAD CoE Environmental Radioactivity, Department of Environmental Sciences, \\ Norwegian University of Life Sciences, 1432 Ås, Norway \\ Correspondence: Jacqueline S. Chaplow (jgar@ceh.ac.uk)
}

\author{
Received: 11 July 2017 - Discussion started: 27 September 2017 \\ Revised: 17 January 2018 - Accepted: 18 January 2018 - Published: 26 February 2018
}

\begin{abstract}
The dataset "Spatial datasets of radionuclide contamination in the Ukrainian Chernobyl Exclusion Zone" was developed to enable data collected between May 1986 (immediately after Chernobyl) and 2014 by the Ukrainian Institute of Agricultural Radiology (UIAR) after the Chernobyl accident to be made publicly available. The dataset includes results from comprehensive soil sampling across the Chernobyl Exclusion Zone (CEZ). Analyses include radiocaesium $\left({ }^{134} \mathrm{Cs}\right.$ and $\left.{ }^{134} \mathrm{Cs}\right){ }^{90} \mathrm{Sr},{ }^{154} \mathrm{Eu}$ and soil property data; plutonium isotope activity concentrations in soil (including distribution in the soil profile); analyses of "hot" (or fuel) particles from the CEZ (data from Poland and across Europe are also included); and results of monitoring in the Ivankov district, a region adjacent to the exclusion zone.

The purpose of this paper is to describe the available data and methodology used to obtain them. The data will be valuable to those conducting studies within the CEZ in a number of ways, for instance (i) for helping to perform robust exposure estimates to wildlife, (ii) for predicting comparative activity concentrations of different key radionuclides, (iii) for providing a baseline against which future surveys in the CEZ can be compared, (iv) as a source of information on the behaviour of fuel particles (FPs), (v) for performing retrospective dose assessments and (vi) for assessing natural background dose rates in the CEZ.

The CEZ has been proposed as a "radioecological observatory" (i.e. a radioactively contaminated site that will provide a focus for long-term, radioecological collaborative international research). Key to the future success of this concept is open access to data for the CEZ. The data presented here are a first step in this process.

The data and supporting documentation are freely available from the Environmental Information Data Centre (EIDC) under the terms and conditions of the Open Government Licence: https://doi.org/10.5285/782ec8452135-4698-8881-b38823e533bf.
\end{abstract}




\section{Background}

The accident in reactor number four at the Chernobyl Nuclear Power Plant (ChNPP), Ukraine, on 26 April 1986 remains the worst in the history of nuclear power generation. Starting on 27 April the human population and farm animals were evacuated from an area of approximately $3500 \mathrm{~km}^{2}$ to create what has become known as the Chernobyl Exclusion Zone (CEZ). Subsequently, the area administered as the CEZ has increased to approximately $4760 \mathrm{~km}^{2}$. The area of the CEZ in the Ukraine is approximately $2598 \mathrm{~km}^{2}$, with the remainder being in Belarus. The deposition of radionuclides over the CEZ is known to be highly spatially heterogeneous. Releases from the Chernobyl reactor occurred over a period of about 10 days. There is a narrow band of high radioactivity to the west of the reactor (often referred to as the western trace) which represents deposition from the initial explosion (Fig. 1). Higher levels of contamination to the north and to a lesser extent the south are a consequence of releases over the days following the accident.

The CEZ has many features making it an important radioecological study site:

- Contamination levels are such that the behaviour, transfer and mobility of a number of radionuclides can be studied $\left({ }^{137} \mathrm{Cs},{ }^{90} \mathrm{Sr},{ }^{241} \mathrm{Am}, \mathrm{Pu}\right.$ isotopes, $\mathrm{U}$ isotopes, ${ }^{129} \mathrm{I},{ }^{14} \mathrm{C},{ }^{36} \mathrm{Cl}$ and $\left.{ }^{99} \mathrm{Tc}\right)$.

- The presence of radioactive particles means that their behaviour in the environment can be studied (Kashparov et al., 1999; Beresford et al., 2016). Fuel particles (FPs) are weathered with time such that mobilisation of ${ }^{90} \mathrm{Sr}$ has been observed to lead to increased contamination of plants (Salbu et al., 1994; Oughton et al., 1993; Kashparov et al., 1999). Fuel particles were released in two different forms (Kashparov et al., 1996): non-oxidised fuel particles of the initial release (26 April 1986) formed by the mechanical destruction of nuclear fuel - these first particles formed a $100 \mathrm{~km}$ long and up to $1 \mathrm{~km}$ wide path to the west of the plant - and oxidised fuel particles which were formed during the subsequent reactor fire (from 26 April to 5 May 1986) and deposited to the north and south of the plant.

- Dose rates remain sufficiently high that we may expect to observe effects on wildlife in some areas. Furthermore, published results on radiation effects from the CEZ are contentious with a lack of agreement on interpretation amongst scientists and a high public profile (Beresford and Copplestone, 2011).

- A wide range of terrestrial and aquatic species and habitats are present. The Ukrainian area, the focus of this paper, contains forests, abandoned farmlands, wetlands, flowing and standing waters, deserted villages and urban areas.
Recently, the CEZ was suggested as a radioecological observatory (http://www.radioecology-exchange.org/ content/radioecological-observatories; Steiner et al., 2013); i.e. a radioactively contaminated site that will provide a focus for joint, long-term, radioecological research which will help address challenges identified for the field of radioecology (Hinton et al., 2013). For this to be successful, relevant data for the CEZ need to be made openly available; indeed the deficiency of open data has been highlighted as one of the causes for the lack of scientific consensus with regard to published studies from within the CEZ and more recently areas affected by the 2011 Fukushima accident (Beresford et al., 2012a, b; Barnett and Welch, 2016).

In this paper we describe a series of datasets focussed on radionuclide deposition and radioactive particles within and around the CEZ predominantly from studies conducted by the Ukrainian Institute of Agricultural Radiology (UIAR, 1998) (now part of the National University of Life and Environmental Sciences of Ukraine, NUBIP). The accompanying data are freely available (https://doi.org/10.5285/782ec8452135-4698-8881-b38823e533bf) under the terms of the Open Government Licence. With respect to radioactive particles, data are also presented from samples collected in Poland in 1986.

The purpose of this paper is to describe the available data and methodology used to obtain them. The data will be valuable to those conducting studies within the CEZ in a number of ways, for instance (i) for helping to perform robust exposure estimates to wildlife (Beaugelin-Seiller et al., 2018), (ii) for predicting comparative activity concentrations of different key radionuclides, (iii) for providing a baseline against which future surveys in the CEZ can be compared, (iv) as a source of information on the behaviour of fuel particles, (v) for performing retrospective dose assessments and (vi) for assessing natural background dose rates in the CEZ.

Whilst many of the results of the studies described have previously been used for various purposes within refereed or other publications (e.g. Kashparov et al., 2001, 2004, 2006; Kashparov, 2003; Zhurba et al., 2009), the complete underlying datasets have not previously been published. The dataset described here results from detailed samplings in the Ukraine and add to the now openly available Chernobyl soil contamination and deposition data for wider areas of the former Soviet Union and Western Europe (Chaplow et al., 2015a, b; Evangeliou et al., 2016).

\section{Data}

There are six datasets available in Kashparov et al. (2017) and an overview of the contents of each is presented below and in Table 1:

1. Spatial dataset of radiocaesium, ${ }^{90} \mathrm{Sr}$ and soil chemistry parameters resulting from a soil sampling exercise conducted during the summer of 1997. The dataset com- 


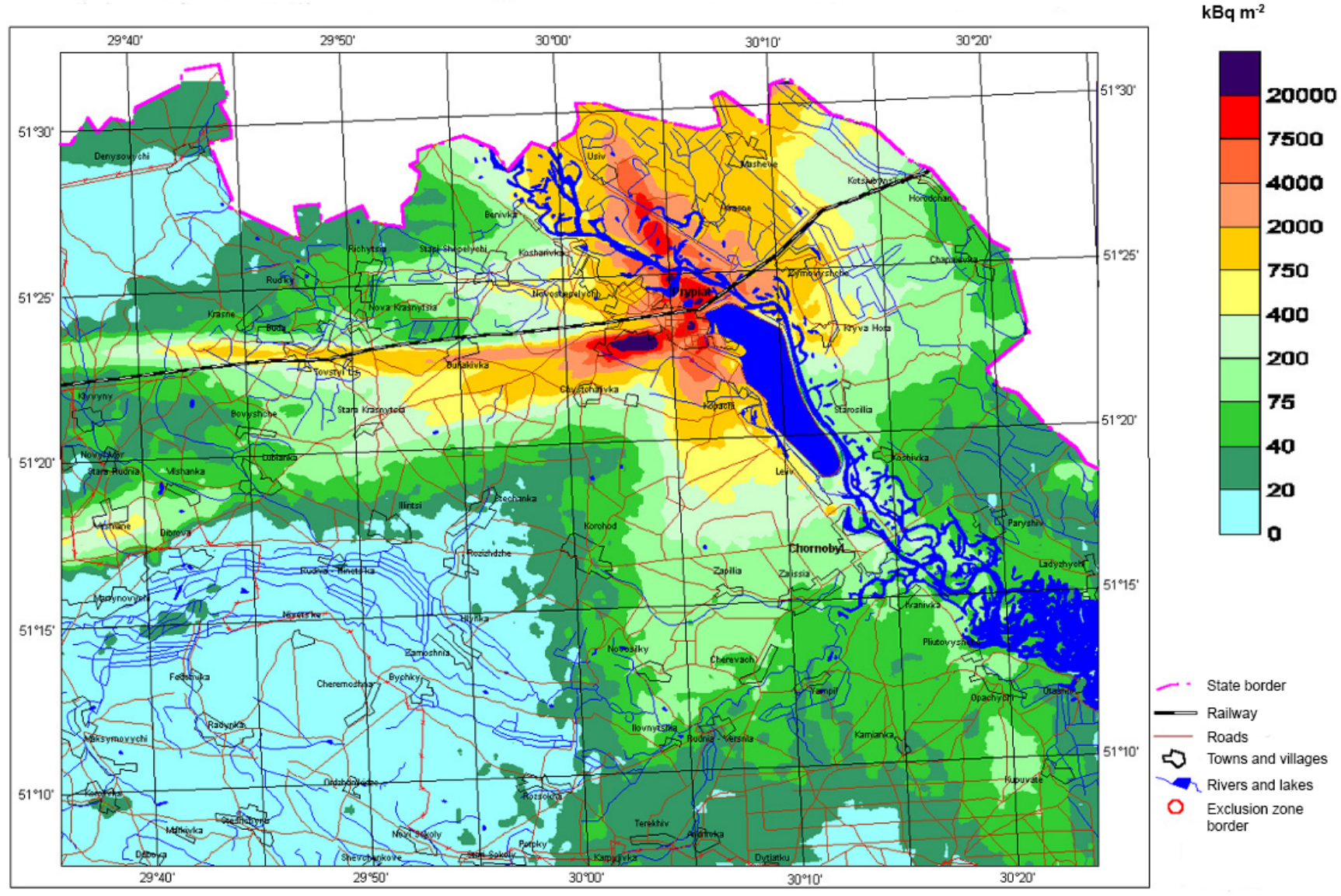

Figure 1. Spatial pattern of ${ }^{90} \mathrm{Sr}$ contamination $\left(\mathrm{kBq} \mathrm{m}^{-2}\right)$ estimated for 1997 (UIAR, 1998).

Table 1. A description of the data presented in this paper and available from Kashparov et al., 2017.

\begin{tabular}{|c|c|c|c|c|}
\hline Dataset ID & Date sampled & Sample description & Radionuclides reported & $\begin{array}{l}\text { Other parameters } \\
\text { reported }\end{array}$ \\
\hline 1 & 1995, 1999, 2000, 2002 & Soil & $\begin{array}{l}{ }^{134} \mathrm{Cs},{ }^{137} \mathrm{Cs},{ }^{90} \mathrm{Sr},{ }^{154} \mathrm{Eu} \\
{ }^{238} \mathrm{Pu},{ }^{239,240} \mathrm{Pu}\end{array}$ & $\begin{array}{l}\text { Soil chemistry and soil } \\
\text { type }\end{array}$ \\
\hline 2 & 1997, 2000, 2002 & Soil & ${ }^{238} \mathrm{Pu},{ }^{239,240} \mathrm{Pu}$ & None \\
\hline 3 & 2000,2001 & Soil & ${ }^{137} \mathrm{Cs},{ }^{90} \mathrm{Sr},{ }^{238} \mathrm{Pu},{ }^{239,240} \mathrm{Pu}$ & $\begin{array}{l}\text { Depth and mass of soil } \\
\text { layers }\end{array}$ \\
\hline 4 & $\begin{array}{l}\text { Gamma: 1986, 1987, } 1988, \\
\text { 1989, 1991, 1992, 1995, 1997, } \\
\text { 1998, 1999, } 2000 \\
\text { Alpha: } 1986,1988,1990,1991 \\
\text { Beta: } 1988,1994,1995\end{array}$ & $\begin{array}{l}\text { "Hot" (or fuel) } \\
\text { particles in soil }\end{array}$ & $\begin{array}{l}{ }^{95} \mathrm{Zr}, \quad{ }^{95} \mathrm{Nb}, \quad{ }^{106} \mathrm{Ru},{ }^{125} \mathrm{Sb}, \\
{ }^{134} \mathrm{Cs},{ }^{137} \mathrm{Cs},{ }^{144} \mathrm{Ce},{ }^{154} \mathrm{Eu}, \\
{ }^{155} \mathrm{Eu},{ }^{54} \mathrm{Mn},{ }^{60} \mathrm{Co},{ }^{241} \mathrm{Am} \\
\text { Total alpha } \\
{ }^{90} \mathrm{Sr}\end{array}$ & $\begin{array}{l}\text { Particle description } \\
\text { (type, size, view, } \\
\text { colour, structure), } \\
\text { burn-up value }\end{array}$ \\
\hline 5 & $1995,1996,1997$ & $\begin{array}{l}\text { Soil and hot } \\
\text { (or fuel) particles }\end{array}$ & ${ }^{85} \mathrm{Sr},{ }^{90} \mathrm{Sr}$ & None \\
\hline 6 & 2014 & $\begin{array}{l}\text { Soil and background } \\
\text { dose rate }\end{array}$ & ${ }^{137} \mathrm{Cs},{ }^{90} \mathrm{Sr},{ }^{40} \mathrm{~K},{ }^{226} \mathrm{Ra},{ }^{232} \mathrm{Th}$ & Sample mass \\
\hline
\end{tabular}


prises results from 1200 soil samples reporting ${ }^{134} \mathrm{Cs}$, ${ }^{137} \mathrm{Cs},{ }^{90} \mathrm{Sr}$ and some ${ }^{154} \mathrm{Eu}$ activities in soil $\left(\mathrm{kBq} \mathrm{m}^{-2}\right)$; some chemical parameters for soils (e.g. pH, exchangeable Cs, percentage humus); soil type at the sampling site; and latitude-longitude co-ordinates. The dataset also contains information for additional samples from some of the datasets below (e.g. this dataset contains radionuclide activity in soil for all sampling though for some of these there are no corresponding soil chemistry data).

2. Pu isotope measurements in bulk soil samples reporting results for the analyses of ${ }^{238} \mathrm{Pu}$ and ${ }^{239,240} \mathrm{Pu}$ on a subset of 82 of the samples from the above dataset and an additional 12 samples collected from within the CEZ and outside it to a distance of $200 \mathrm{~km}$ between 2000 and 2001.

3. Pu isotope measurements in sectioned soil samples reporting results from cores sectioned at different depths collected at 9 of the 12 sites sampled between 2000 and 2001.

4. "Hot" or fuel particle dataset presenting radionuclide activity and some physical characteristics of (i) 1380 hot particles (predominantly fuel particles) extracted from soils collected in the CEZ (largely from in the inner $10 \mathrm{~km}$ zone) over the period 1987 to 2000, (ii) 206 particles collected from the northeast and Warsaw area (Poland) in September 1986 (data courtesy of Warsaw University; Dabrowska et al., 1987; Osuch et al., 1989), (iii) 294 particles collected from within the "shelter" (or sarcophagus) in 1992 and (iv) data from published literature on particles collected in different European countries between 1986 and 1987.

5. The fuel particle dissolution dataset presents results from studies on 115 soil samples, collected within the CEZ between 1995 and 1997, to determine the proportion of undissolved fuel particles.

6. The Ivankov district dataset presents unreported data of a survey of the Ivankiv Raion, a district in the Kiev Oblast immediately to the south of the CEZ, conducted in 2014. The Ivankov district borders the CEZ and Ivankov; the administrative centre is situated $\sim 80 \mathrm{~km}$ from Kiev and $\sim 50 \mathrm{~km}$ from the Chernobyl NPP. The dataset contains dose rates measured at approximately 3400 sites across the Ivankov district and activity concentrations of ${ }^{90} \mathrm{Sr},{ }^{137} \mathrm{Cs}$ and natural series gammaemitting radionuclides in 547 soil samples sampled in 2014.

The above numbers are used in Table 1 and subsequently to identify the datasets.

Locations of sampling for studies 1, 2, 3 and 5 are presented in Fig. 2 and those for the Ivankov district are shown in Fig. 3. Reported activity concentrations for all datasets discussed are presented for the date of measurement which is provided in the accompanying datasets.

\section{Overview of studies and available data}

\subsection{Spatial dataset of radiocaesium, ${ }^{90} \mathrm{Sr}$ and soil chemistry parameters}

\subsubsection{Soil sampling}

Soil samples were collected at about 1200 sites in the Ukrainian CEZ in an area of $36 \mathrm{~km}$ radius around ChNPP between July 1995 and September 1997. Sites were selected using a grid and the approximate distance between sampling sites was about $1.2 \mathrm{~km}$. For the narrow western (fuel particle) trace of the radioactive release, where contamination is characterised by a high gradient, the distance between the sampling sites was reduced to 100 to $500 \mathrm{~m}$. Because of the large area of the CEZ, the majority of the sampling was conducted using a helicopter to rapidly move between sites; to sample forest areas motor vehicles were used for transport.

At each sampling point, the absorbed dose rate at a height of $1 \mathrm{~m}$ above ground surface was measured. Before soil sampling the homogeneity of the site $(100 \times 100 \mathrm{~m})$ was evaluated by measurement of absorbed dose rate at several points using a DRG-01T dosimeter ("Mekhanichesky zavod", mechanical plant, Russia).

Composite soil samples were collected using the envelope method now referred to as SOU 74.14-37-425:2006. Five individual soil cores were taken to a depth of $30 \mathrm{~cm}$, four from the corners and one from the centre of a plot that measured between 2 and $5 \mathrm{~m}^{2}$. The samples were subsequently combined to form a composite. SOU refers to the standard of the Ministry of Agrarian Policy and Food of Ukraine (industry standard of Ukraine). This approach was developed to obtain a representative soil sample (Khomutinin et al., 2001). The total mass was not less than $2 \mathrm{~kg}$ for the five cores. The sampling depth of $30 \mathrm{~cm}$ was chosen because it had been shown that 10 years after the accident about $95 \%$ of the ${ }^{90} \mathrm{Sr}$ activity is associated with the upper 10 to $20 \mathrm{~cm}$ layer (Ivanov et al., 1997). To test that the sampling depth was adequate the vertical distribution of ${ }^{90} \mathrm{Sr}$ in sandy soil profiles (up to $1 \mathrm{~m}$ depth) was determined and the ${ }^{90} \mathrm{Sr}:{ }^{154}$ Eu activity ratio in the samples was measured. Fuel particles have a characteristic ${ }^{90} \mathrm{Sr}:{ }^{154} \mathrm{Eu}$; if this ratio deviates from that expected it is indicative of ${ }^{90} \mathrm{Sr}$ being leached down the profile. In most of the cores more that $95 \%$ of the ${ }^{90} \mathrm{Sr}$ was located in the upper $30 \mathrm{~cm}$ layer. Only in a few sites (less than $0.1 \%$ of all sites) with a low organic matter content was there a significant percentage of ${ }^{90} \mathrm{Sr}(>20 \%)$ that had migrated deeper than $30 \mathrm{~cm}$ (Shestopalov et al., 2003).

The co-ordinates of the sampling sites were determined by means of a GPS receiver (ScoutMaster) using the WGS-84 (world) system. In order to estimate the accuracy of the coordinates and their correspondence to the topographic basis, 

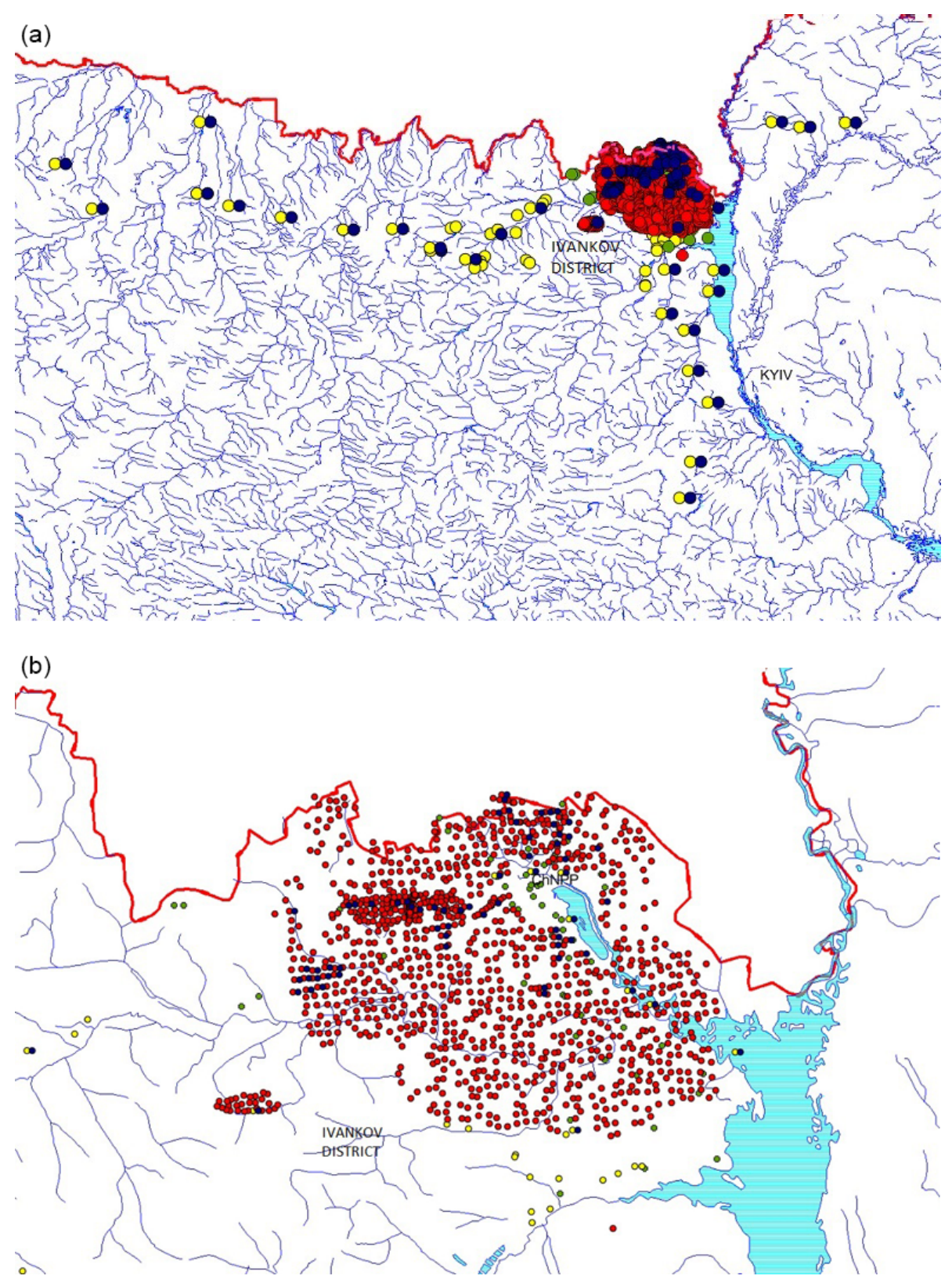

Figure 2. Sampling locations for the different studies in the CEZ (red - (1) spatial dataset of radiocaesium, ${ }^{90} \mathrm{Sr}$ and soil chemistry parameters; dark blue - (2) Pu isotope measurements in bulk soil samples; yellow - (3) Pu isotope measurements in sectioned soil samples; green (5) fuel particle dissolution dataset; (6) Ivankov district (sampling locations see Fig. 3).

GPS measurements were performed at several points with known co-ordinates. It was shown that the accuracy of the GPS receiver was about $100 \mathrm{~m}$ with a systematic deviation of about $300 \mathrm{~m}$.

The same methodology was used for estimating radionuclide activity concentrations in the other data described below unless otherwise indicated.

\subsubsection{Soil activity measurements}

The collected soil samples were dried, sieved through a $1 \mathrm{~mm}$ sieve and homogenised. Four subsamples were taken from each sample for the determination of the total contents of radionuclides: three subsamples of $100 \mathrm{~cm}^{3}$ volume and one of $1000 \mathrm{~cm}^{3}$ volume for the measurement of gammaemitting radionuclides in a Marinelli container. Measurements of gamma-emitting radionuclide contents were performed on all four subsamples $\left(\mathrm{C}_{i}, \mathrm{~Bq} \mathrm{~kg}^{-1}\right)$ using gamma spectrometry. If the relative difference of the subsample 


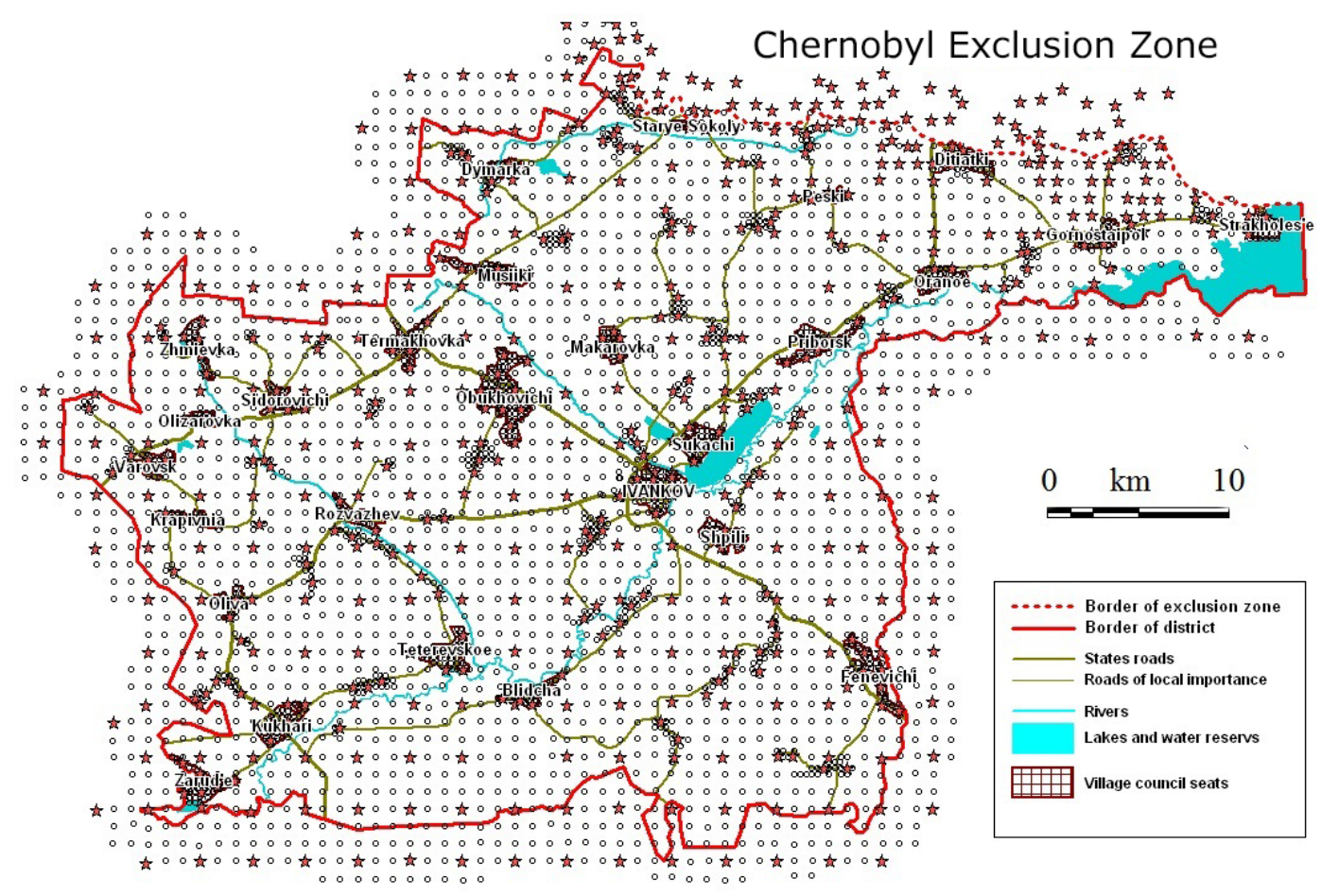

Figure 3. Map of the soil sampling locations in the Ivankov district which borders the CEZ: soil sampling and gamma survey (red stars); gamma survey only (grey circles).

measurements $\left(\mathrm{C}_{\max }-\mathrm{C}_{\min }\right) /\left(\mathrm{C}_{\max }+\mathrm{C}_{\min }\right)$ exceeded 0.15 for the ${ }^{137} \mathrm{Cs}$ activity concentrations, the subsamples were bulked and remixed. The resultant sample was again divided into replicates which were reanalysed. Once $\left(\mathrm{C}_{\max }-\right.$ $\left.\mathrm{C}_{\min }\right) /\left(\mathrm{C}_{\max }+\mathrm{C}_{\min }\right)$ was $<0.15$, a $100 \mathrm{~cm}^{3}$ subsamples with an approximate average ${ }^{137} \mathrm{Cs}$ activity concentration was chosen for the measurement of the ${ }^{90} \mathrm{Sr}$-specific activity. This procedure was followed to ensure that the subsample analysed for ${ }^{90} \mathrm{Sr}$ was representative of the sample as a whole.

Gamma-spectrometry measurements were performed using high-purity germanium (HPGe) detectors of $30 \%$ relative efficiency and $1.90 \mathrm{keV}$ FWHM for $1333 \mathrm{keV}$ (GEM30185, EG\&G ORTEC, USA) and a multichannel analyser (ADCAM-300, ORTEC, USA) using GammaVision 32 software. The efficiency calibration was carried out for the $1 \mathrm{~L}$ Marinelli geometry using a spiked soil sample containing ${ }^{241} \mathrm{Am},{ }^{243} \mathrm{Am},{ }^{152} \mathrm{Eu},{ }^{154} \mathrm{Eu},{ }^{137} \mathrm{Cs}$ and ${ }^{40} \mathrm{~K}$. The average counting time was about $1 \mathrm{~h}$; for samples of lower activity the counting time was extended to obtain an acceptable error on the measurement $(<30 \%$ at 95 th percentile confidence interval).

The activity of ${ }^{90} \mathrm{Sr}$ was determined using a radiochemical method (Pavlotskaya, 1997) with treatment of the samples by boiling in $6 \mathrm{M}$ nitric acid for $4 \mathrm{~h}$. This method was used to dissolve as much of the fuel particles as possible (Kashparov, 2003); it has been estimated that for particles collected from the western trace within 5 to $10 \mathrm{~km}$ of the ChNPP this method may underestimate ${ }^{90} \mathrm{Sr}$ activity by up to $20 \%$ (Kashparov et al., 2004). After filtration of the solution, hydroxides of high-valence metals ( $\mathrm{Fe}, \mathrm{Al}, \mathrm{Ti}, \mathrm{Mn}, \mathrm{Th}, \mathrm{U}$ ) were extracted by adding ammonia into the solution. After acidification, the solution was left for 3 weeks to reach equilibrium between ${ }^{90} \mathrm{Sr}$ and ${ }^{90} \mathrm{Y}$. Subsequently, stable Y was added to the solution and $\mathrm{Y}$ precipitated by addition of ammonia. The precipitate was incinerated to yield $\mathrm{Y}_{2} \mathrm{O}_{3}$ and after 1 day (to allow the decay or radium daughters) ${ }^{90} \mathrm{Sr}$ was measured using a low-background beta counter (CANBERRA-2400, USA).

The radiochemical procedure removed ${ }^{137} \mathrm{Cs}$ from the sample which increased the accuracy of the subsequent ${ }^{154}$ Eu gamma-spectrometric measurements to determine the ${ }^{90} \mathrm{Sr}:{ }^{154} \mathrm{Eu}$ ratio (gamma counting to determine the ${ }^{154} \mathrm{Eu}$ activity was conducted after extraction of high-valence metals).

\subsubsection{Determination of the main agrochemical characteristics}

Standard methods were used to determine soil chemistry: humus or organic matter content was determined by GOST 26213-91 (Derzhavin et al., 1991a); $\mathrm{pH}_{\mathrm{H}_{2} \mathrm{O}}$ by GOST 2642385 (Derzhavin et al., 1985a); $\mathrm{pH}_{\mathrm{Kcl}}$ by GOST 26483-85 (Derzhavin et al., 1985b); hydrolytic acidity was determined using the Kappen method or GOST 26212-91 (Derzhavin et al., 1991c); exchangeable Ca was determined by GOST 26487-85 (Derzhavin et al., 1985c); and exchangeable K and 
Table 2. Soil classifications appropriate to the CEZ.

\begin{tabular}{|c|c|c|c|}
\hline Code used in data & Ex-USSR (including Ukraine) classification & & FAO-UNESCO \\
\hline 1 & Soddy underdeveloped & \multirow{9}{*}{ Soddy-podzolic } & \multirow{9}{*}{ Podzoluvisol } \\
\hline 2 & Soddy slightly and mid-podzolic sandy and consolidated sandy & & \\
\hline 3 & Soddy slightly podzolic sandy loam and loamy & & \\
\hline 4 & Soddy mid-podzolic sandy loam and loamy & & \\
\hline 6 & Soddy slightly podzolic gleyic sandy and consolidated sandy & & \\
\hline 7 & Soddy slightly podzolic gleyic sandy loam and loamy & & \\
\hline 8 & Soddy mid- and heavy-podzolic gleyic sandy loamy & & \\
\hline 9 & Soddy slightly podzolic gleyic sandy and consolidated sandy & & \\
\hline 10 & Soddy mid- and heavy-podzolic gleyic sandy loam and loamy & & \\
\hline 18 & Grey forest & \multirow{2}{*}{ Grey forest } & \multirow{2}{*}{ Greyzems } \\
\hline 19 & Dark-grey forest & & \\
\hline 121 & Meadow gleyic & Gleyic & Gleysols \\
\hline 122 & Meadow and soddy gleyic carbonate & \multirow{3}{*}{ Meadow } & \multirow{3}{*}{ Phaeozems } \\
\hline 124 & Meadow pseudopodzolic and meadow pseudopodzolic gleyic & & \\
\hline 131 & Meadow boggy & & \\
\hline 133 & Boggy & \multirow{4}{*}{ Peat, boggy } & \multirow{4}{*}{ Histosols } \\
\hline 135 & Peaty boggy & & \\
\hline 136 & Peat boggy & & \\
\hline 138 & Low moor peat & & \\
\hline 159 & Soddy gleyic sandy and consolidated sandy & Soddy & Arenosols \\
\hline 160 & Slightly soddy low-humus and non-humus sand & Alluvial & Fluvisols \\
\hline 161 & Soddy sandy loam and loamy & \multirow{4}{*}{ Soddy } & \multirow{4}{*}{ Arenosols } \\
\hline 162 & Soddy gleyic sandy loam and loamy & & \\
\hline 167 & Soddy solod & & \\
\hline 168 & Soddy pseudopodzolic gleyic & & \\
\hline
\end{tabular}

$\mathrm{P}$ contents were determined using a method appropriate to the specific soil type, i.e. GOST 26207-91 (Derzhavin et al., 1991b) or GOST 26204-91 (Derzhavin et al., 1991d). GOST refers to the national standard of the USSR and Ukraine prior to the break-up of the Soviet Union in 1991.

Mechanical composition (i.e. percent clay, percent silt, sand) were determined on the soils but not reported in the data. Instead, they have been used to attribute soils to the USSR classification system. Table 2 presents soil types in the CEZ described using USSR classification and in accordance with the FAO/UNESCO system (Stolbovoi, 2000). The soil type at each sampling site was attributed to one of these codes and this is presented within the data.

Codes 116 to 143 in the data were sampled from around the village of Bober which was not within the CEZ but at which high deposition values were found. No agrochemical measurements were made at these sites except $\mathrm{pH}$.

\subsection{Pu isotope measurements}

From the dataset described above, 82 samples from sites along the main traces of the release were selected for analysis of $\mathrm{Pu}$ isotopes. For determination of plutonium radioisotopes at a given site, one of the homogenised $100 \mathrm{~cm}^{3}$ samples was used. After heating at $450^{\circ} \mathrm{C}$ overnight, the samples were boiled for $4 \mathrm{~h}$ in $6 \mathrm{M} \mathrm{HNO}_{3}$. Plutonium radioisotopes were extracted by a standard radiochemical method (Pavlotskaya, 1997). Chemical yield was calculated using ${ }^{236} \mathrm{Pu}$ or ${ }^{242} \mathrm{Pu}$ as tracers. Plutonium was extracted from the resultant solution using ion-exchange resin (VP-1AP, Russia). After elution and evaporation plutonium was extracted by electrical deposition onto stainless steel plates. Activities on the plates were measured using a Soloist alpha-spectrometer equipped with a Soloist-U0300 detector (EG\&G ORTEC, USA).

An additional set of 12 samples were collected in autumn 2000 and analysed to determine $\mathrm{Pu}$ isotopes using the same methodology. These samples were collected at distances of up to $200 \mathrm{~km}$ outside of the CEZ in westerly, southerly and easterly directions.

\subsection{Pu isotope measurements at different depths}

Apart from having total $\mathrm{Pu}$ isotopes determined as above for the bulked soil sample, cores from eight of these sampling sites were sectioned into layers $(0-2,2-4,4-6,6-8,8-10$, 
$10-15,15-20,20-25$ and $25-30 \mathrm{~cm}$ ) and analysed for Pu isotopes, ${ }^{137} \mathrm{Cs}$ and ${ }^{90} \mathrm{Sr}$.

A further site close to Pripyat was sampled in 2001 to a depth of $110 \mathrm{~cm}$ and the core was sectioned into $10 \mathrm{~cm}$ slices (these are identified as $1 \_\mathrm{J} \_w$ in the accompanying datasets). Each of these depth samples was analysed to determine ${ }^{238} \mathrm{Pu},{ }^{239,240} \mathrm{Pu},{ }^{137} \mathrm{Cs}$ and ${ }^{90} \mathrm{Sr}$ as described above.

\subsection{Hot or fuel particles}

The initial explosion in the Chernobyl reactor released a large amount of uranium dioxide fuel particles with a median radius of 2-3 $\mu \mathrm{m}$ which were deposited in a narrow band up to $100 \mathrm{~km}$ to the west of the ChNPP (Kashparov et al., 1999). The explosion also released relatively large fuel fragments ranging from tens to hundreds of micrometres in size. These larger fragments were predominantly deposited at a distance of $2-5 \mathrm{~km}$ from the reactor (Kashparov et al., 1999). The deposition of particles was a distinguishing feature of radioactive contamination of the Chernobyl accident and the behaviour of radionuclides associated with such particles in the environment had not previously been considered (Loshchilov et al., 1991; Beresford et al., 2016).

In 1987, the State Committee of Hydrometeorology of the USSR and the Scientific Centre of the Defence Ministry of the USSR created a regular sampling network in the CEZ (Loshchilov et al., 1991). Fifteen points were chosen on each of 36 transects defined at $10^{\circ}$ intervals within $60 \mathrm{~km}$ of the ChNPP. Soil samples were collected during 1987 and 1989 at each point, except for those located in woods, rivers and lakes; the majority of sampling sites were located within the inner $10 \mathrm{~km}$ of the CEZ. The samples $(15 \mathrm{~cm}$ in diameter and $5 \mathrm{~cm}$ deep) were measured in Marinelli beakers using a highpurity Ge detector. From a subset of these samples, all collected within the $30 \mathrm{~km}$ zone, more than 1200 relatively large (size $>10 \mu \mathrm{m}$ ) hot particles (activity $>100 \mathrm{~Bq}$ ) were identified and isolated by scanning thin soil layers with a dosimeter (Kuriny et al., 1993). In some instances more than one particle was extracted from the same soil sample (in the data the identifier code starts with the same number).

About 500 additional hot or fuel particles were collected in a similar manner from soils sampled using the same approach in the CEZ during the period 1989-1996 (Kashparov, 2003). In the inner zone of the CEZ, where these samples were collected, up to $97 \%$ of particles comprised finely dispersed nuclear fuel particles. The other $3 \%$ were what are known as ruthenium or condensed particles, a matrix of iron group elements with a high content of ${ }^{103,106} \mathrm{Ru}$ (Kashparov et al., 1996). Condensed particles were formed when highly volatile radionuclides released from the fuel matrix were condensed onto particles of dust, construction materials, etc. (Kashparov et al., 1996). Within the database the type of each particle is identified as fuel or condensed.

The specific activity of the fuel particles corresponded to the activity of the fuel at the moment of the accident, ex- cluding the volatile and highly mobile radionuclides such as ${ }^{134,137} \mathrm{Cs}$ and ${ }^{103,106} \mathrm{Ru}$ (Kuriny et al., 1993; Kashparov, 2003). The presence of fissionable material in the particles was demonstrated using neutron-activation analysis, electron probe microanalysis and laser mass spectrometry. Particle enrichment with ${ }^{235} \mathrm{U}$ was found to be about 1 to $2 \%$ (Kashparov et al., 1996); natural uranium consists of approximately $0.7 \%{ }^{235} \mathrm{U}$ (USNRC, 2017). Particle size and radionuclide activity were measured by optical microscopy and by alpha, beta and gamma spectrometry respectively. Gamma spectrometry was conducted using a high-purity germanium detector (GEM-30185, EG\&G ORTEC, USA) of about $30 \%$ efficiency and $1.85 \mathrm{keV}$ energy resolution (for ${ }^{60} \mathrm{Co}, 1332 \mathrm{keV}$ gamma rays) connected to a multichannel analyser (ADCAM ${ }^{\mathrm{TM}}$ MCA 350, EG\&G ORTEC, USA). Alpha spectrometry was conducted using a gold-silicon detector (DKP-125-IA) linked to a SES-13 spectrometer. Following radiochemical separation using the methodology described above ${ }^{90} \mathrm{Sr}$ activity was determined using an alphabeta detector (CANBERRA-2400, USA).

An additional set of 294 particles were obtained from inside of the shelter (or sarcophagus) in the reactor hall of the Chernobyl no. 4 unit early in 1992 and analysed as described above.

Using the ${ }^{137} \mathrm{Cs}$ and ${ }^{90} \mathrm{Sr}$ results for the particles, Kashparov (2003) estimated the effective duration and temperature for fuel particle annealing to be $\sim 3.5 \mathrm{~s}$ at $2400 \mathrm{~K}$ respectively for particles of $>10 \mu \mathrm{m}$ from the western trace. This confirmed an explosion-like mechanism of fuel particle formation during the accident (Kashparov, 2003).

For particles collected in the CEZ the dataset presents "burn-up" values. Burn-up is used to describe the fraction of fuel atoms having undergone fission. The burn-up distribution of fuel particles larger than $10 \mu \mathrm{m}$ collected from the CEZ indicated that, at the moment of the accident, particles were released from the less irradiated ("younger") part of the reactor core. Burn-up values were lower in these particles $\left(9.8-11 \mathrm{MW}\right.$ day $\left.\mathrm{kg}^{-1}\right)$ in comparison with the estimated most probable fuel burn-up value of $14 \mathrm{MW}$ day $\mathrm{kg}^{-1}$ in the fourth unit of the ChNPP (Kuriny et al., 1993; Kashparov et al., 1996, 1997; Begichev et al., 1990). Table 3 presents estimated radionuclide activity concentrations at the time of the accident in fuel with different burn-up values. The lower burn-up of fuel contributing to particles within the CEZ resulted in particles with less radioactivity than if deposited particles had been largely formed from "older" fuel in the reactor.

The dataset also contains information on 206 particles collected from five areas in the northeast of Poland. Particles were collected in autumn 1986 from wasteland and forest clearings; the total area sampled was approximately $6000 \mathrm{~m}^{2}$ (the data are supplied courtesy of Warsaw University; see Dabrowska et al., 1988, and Osuch et al., 1989, for methodology). In contrast to the CEZ, $>40 \%$ of the particles collected in Poland were of the condensed form; the results for the 
Table 3. The activity concentrations of radionuclides in the ChNPP fourth unit nuclear fuel with different burn-up, Bq $\mathrm{g}^{-1}$.

\begin{tabular}{lccccccccc}
\hline $\begin{array}{l}\text { Burn-up } \\
\left(\mathrm{MW} \mathrm{d} \mathrm{kg}^{-1}\right)\end{array}$ & ${ }^{90} \mathrm{Sr}$ & ${ }^{95} \mathrm{Zr}$ & ${ }^{106} \mathrm{Ru}$ & ${ }^{134} \mathrm{Cs}$ & ${ }^{137} \mathrm{Cs}$ & ${ }^{144} \mathrm{Ce}$ & ${ }^{125} \mathrm{Sb}$ & ${ }^{154} \mathrm{Eu}$ & ${ }^{155} \mathrm{Eu}$ \\
\hline 15.20 & $1.54 \mathrm{E}+09$ & $3.43 \mathrm{E}+10$ & $9.66 \mathrm{E}+09$ & $1.33 \mathrm{E}+09$ & $1.91 \mathrm{E}+09$ & $2.73 \mathrm{E}+10$ & $2.64 \mathrm{E}+08$ & $5.52 \mathrm{E}+07$ & $6.48 \mathrm{E}+07$ \\
14.30 & $1.46 \mathrm{E}+09$ & $3.46 \mathrm{E}+10$ & $8.85 \mathrm{E}+09$ & $1.16 \mathrm{E}+09$ & $1.80 \mathrm{E}+09$ & $2.69 \mathrm{E}+10$ & $2.38 \mathrm{E}+08$ & $4.91 \mathrm{E}+07$ & $6.01 \mathrm{E}+07$ \\
13.40 & $1.38 \mathrm{E}+09$ & $3.48 \mathrm{E}+10$ & $8.09 \mathrm{E}+09$ & $1.01 \mathrm{E}+09$ & $1.69 \mathrm{E}+09$ & $2.65 \mathrm{E}+10$ & $2.13 \mathrm{E}+08$ & $4.33 \mathrm{E}+07$ & $5.54 \mathrm{E}+07$ \\
12.50 & $1.30 \mathrm{E}+09$ & $3.50 \mathrm{E}+10$ & $7.36 \mathrm{E}+09$ & $8.74 \mathrm{E}+08$ & $1.58 \mathrm{E}+09$ & $2.59 \mathrm{E}+10$ & $1.89 \mathrm{E}+08$ & $3.81 \mathrm{E}+07$ & $5.12 \mathrm{E}+07$ \\
11.60 & $1.22 \mathrm{E}+09$ & $3.51 \mathrm{E}+10$ & $6.67 \mathrm{E}+09$ & $7.49 \mathrm{E}+08$ & $1.47 \mathrm{E}+09$ & $2.53 \mathrm{E}+10$ & $1.68 \mathrm{E}+08$ & $3.32 \mathrm{E}+07$ & $4.69 \mathrm{E}+07$ \\
10.70 & $1.14 \mathrm{E}+09$ & $3.53 \mathrm{E}+10$ & $6.01 \mathrm{E}+09$ & $6.35 \mathrm{E}+08$ & $1.36 \mathrm{E}+09$ & $2.46 \mathrm{E}+10$ & $1.47 \mathrm{E}+08$ & $2.87 \mathrm{E}+07$ & $4.27 \mathrm{E}+07$ \\
9.84 & $1.05 \mathrm{E}+09$ & $3.54 \mathrm{E}+10$ & $5.38 \mathrm{E}+09$ & $5.33 \mathrm{E}+08$ & $1.24 \mathrm{E}+09$ & $2.37 \mathrm{E}+10$ & $1.29 \mathrm{E}+08$ & $2.46 \mathrm{E}+07$ & $3.86 \mathrm{E}+07$ \\
8.94 & $9.61 \mathrm{E}+08$ & $3.55 \mathrm{E}+10$ & $4.78 \mathrm{E}+09$ & $4.41 \mathrm{E}+08$ & $1.13 \mathrm{E}+09$ & $2.27 \mathrm{E}+10$ & $1.11 \mathrm{E}+08$ & $2.09 \mathrm{E}+07$ & $3.47 \mathrm{E}+07$ \\
8.05 & $8.72 \mathrm{E}+08$ & $3.56 \mathrm{E}+10$ & $4.21 \mathrm{E}+09$ & $3.60 \mathrm{E}+08$ & $1.02 \mathrm{E}+09$ & $2.16 \mathrm{E}+10$ & $9.48 \mathrm{E}+07$ & $1.76 \mathrm{E}+07$ & $3.09 \mathrm{E}+07$ \\
7.15 & $7.80 \mathrm{E}+08$ & $3.55 \mathrm{E}+10$ & $3.66 \mathrm{E}+09$ & $2.87 \mathrm{E}+08$ & $9.09 \mathrm{E}+08$ & $2.03 \mathrm{E}+10$ & $7.98 \mathrm{E}+07$ & $1.45 \mathrm{E}+07$ & $2.72 \mathrm{E}+07$ \\
6.26 & $6.88 \mathrm{E}+08$ & $3.53 \mathrm{E}+10$ & $3.14 \mathrm{E}+09$ & $2.24 \mathrm{E}+08$ & $7.96 \mathrm{E}+08$ & $1.88 \mathrm{E}+10$ & $6.60 \mathrm{E}+07$ & $1.17 \mathrm{E}+07$ & $2.36 \mathrm{E}+07$ \\
5.36 & $5.93 \mathrm{E}+08$ & $3.48 \mathrm{E}+10$ & $2.63 \mathrm{E}+09$ & $1.69 \mathrm{E}+08$ & $6.83 \mathrm{E}+08$ & $1.70 \mathrm{E}+10$ & $5.34 \mathrm{E}+07$ & $9.22 \mathrm{E}+06$ & $2.01 \mathrm{E}+07$ \\
4.47 & $4.98 \mathrm{E}+08$ & $3.39 \mathrm{E}+10$ & $2.15 \mathrm{E}+09$ & $1.22 \mathrm{E}+08$ & $5.70 \mathrm{E}+08$ & $1.50 \mathrm{E}+10$ & $4.18 \mathrm{E}+07$ & $7.08 \mathrm{E}+06$ & $1.66 \mathrm{E}+07$ \\
3.58 & $4.01 \mathrm{E}+08$ & $3.23 \mathrm{E}+10$ & $1.68 \mathrm{E}+09$ & $8.32 \mathrm{E}+07$ & $4.57 \mathrm{E}+08$ & $1.27 \mathrm{E}+10$ & $3.14 \mathrm{E}+07$ & $5.15 \mathrm{E}+06$ & $1.32 \mathrm{E}+07$ \\
2.68 & $3.03 \mathrm{E}+08$ & $2.93 \mathrm{E}+10$ & $1.24 \mathrm{E}+09$ & $5.17 \mathrm{E}+07$ & $3.43 \mathrm{E}+08$ & $1.01 \mathrm{E}+10$ & $2.20 \mathrm{E}+07$ & $3.49 \mathrm{E}+06$ & $9.86 \mathrm{E}+06$ \\
1.79 & $2.03 \mathrm{E}+08$ & $2.42 \mathrm{E}+10$ & $8.07 \mathrm{E}+08$ & $2.74 \mathrm{E}+07$ & $2.29 \mathrm{E}+08$ & $7.19 \mathrm{E}+09$ & $1.36 \mathrm{E}+07$ & $2.09 \mathrm{E}+06$ & $6.53 \mathrm{E}+06$ \\
0.89 & $1.02 \mathrm{E}+08$ & $1.53 \mathrm{E}+10$ & $3.95 \mathrm{E}+08$ & $1.03 \mathrm{E}+07$ & $1.15 \mathrm{E}+08$ & $3.82 \mathrm{E}+09$ & $6.30 \mathrm{E}+06$ & $9.27 \mathrm{E}+05$ & $3.24 \mathrm{E}+06$ \\
\hline
\end{tabular}

Polish particles were decay corrected to the day of the accident. The Polish particles were divided into three forms: A, B and C. Group A contained mostly ${ }^{103} \mathrm{Ru}$ and ${ }^{106} \mathrm{Ru}$ isotopes, group $\mathrm{B}$ particles were rich in other nuclides from the fission product spectrum and group $\mathrm{C}$ resembled group $\mathrm{B}$ particles in isotope contents but with a higher abundance of ruthenium.

For completeness and comparison, we have augmented the data with values from the published literature which present information on particles from Bialystok in the Masurian Lake region of northeast Poland (nine particles collected in November 1987) (Schubert and Behrend, 1987); Budapest, Hungary (15 particles collected in July 1986) (Balashazy et al., 1988); Stockholm, Gotland and Gävle in Sweden (41 particles collected in 1987) (Kerekes et al., 1991); Sofia, Bulgaria (five particles) (Mandjoukov et al., 1992). Most of the particles from these studies were also ruthenium condensation particles. Particles were selected in 1986 and activities were decay corrected to the time of the accident.

\subsection{Fuel particle dissolution dataset}

\subsubsection{Soil sampling and preparation}

Between July 1995 and May 1997, 115 soil samples were collected from sites within the CEZ at varying directions and distances from the ChNPP in order to reflect the variability of the physical and chemical characteristics of the fuel particles deposited (Kashparov et al., 1996, 1999, 2004). The sampling was carried out along the narrow western trace of fallout of the non-oxidised fuel particles of the first release (Chernobyl releases occurred over a period of 10 days, Smith and Beresford, 2005) and at the southern and northern fuel traces of fallout of oxidised fuel particles. At all sample sites, soddy podzolic sandy soils (type 2 from Table 2) were sam- pled. Where possible at each site, additional samples were collected from an area of peat soil within a radius of $300 \mathrm{~m}$. It was assumed that within this area the deposited particles would be relatively similar, allowing the effect of soil type on particle behaviour to be studied. Density of contamination by ${ }^{90} \mathrm{Sr}$ varied at the sampling sites from $12 \mathrm{kBq} \mathrm{m}^{-2}$ to $60 \mathrm{MBq} \mathrm{m}^{-2}$.

Two soil cores were collected at each sampling point: one sample was collected to a depth of $5 \mathrm{~cm}$ with a $14 \mathrm{~cm}$ diameter; the second was taken to a depth of $30 \mathrm{~cm}$ with a $6 \mathrm{~cm}$ diameter. The 0 to $5 \mathrm{~cm}$ samples (containing the fuel particles) were used to determine soil $\mathrm{pH}_{\mathrm{H}_{2} \mathrm{O}}$ using the same method as above.

The ${ }^{85} \mathrm{Sr}$ and ${ }^{90} \mathrm{Sr}$ activity concentrations were determined on the 0 to $30 \mathrm{~cm}$ samples which were also used to estimate the fraction of remaining undissolved fuel particles. Soil samples were air dried (approximately $25^{\circ} \mathrm{C}$ ), passed through a $1 \mathrm{~mm}$ mesh sieve and homogenised prior to analysis.

\subsubsection{Estimation of remaining fraction of fuel particles}

The fuel particle component in the soil samples was estimated from the fraction of exchangeable ${ }^{90} \mathrm{Sr}$ determined using a $2 \mathrm{M} \mathrm{NH} \mathrm{NH}_{4} \mathrm{Ac}$ extraction with ${ }^{85} \mathrm{Sr}$ yield monitor (Kashparov et al., 1999). Three or four subsamples of $100 \mathrm{~cm}^{3}$ were taken from each 0 to $30 \mathrm{~cm}$ soil sample, and $5 \mathrm{~mL}$ of ${ }^{85} \mathrm{Sr}$ solution (activity of about $100 \mathrm{~Bq}$ ) and $25 \mathrm{~mL}$ of water were added to each. After 6 to 48 days, the soil was subjected to extraction using $2 \mathrm{M} \mathrm{NH}_{4} \mathrm{Ac}$ (solid : liquid ratio of $1: 10$ ). The soil-extract solution was shaken for $1 \mathrm{~h}$ and left for 1 day. Extractants and soil residues were separated by filtration, and the fraction of radiostrontium was determined in both the 
solution $\left(A_{\text {sol }}\right)$ and the residue $\left(A_{\text {res }}\right)$. The gamma-emitting radionuclides ${ }^{137} \mathrm{Cs},{ }^{154} \mathrm{Eu},{ }^{241} \mathrm{Am}$ and ${ }^{85} \mathrm{Sr}$ were measured using gamma spectrometry and ${ }^{90} \mathrm{Sr}$ by beta counting after radiochemical separation using the approach outlined above.

The percentages of ${ }^{85} \mathrm{Sr}$ and ${ }^{90} \mathrm{Sr}$ leached from soil $\left(\mathrm{D}^{90} \mathrm{Sr}\right.$ and $\mathrm{D}^{85} \mathrm{Sr}$ respectively) were calculated as follows:

$$
\begin{aligned}
& \Delta^{85} \mathrm{Sr}=\left\{\frac{A_{\text {sol }}\left({ }^{85} \mathrm{Sr}\right)}{A_{\text {sol }}\left({ }^{85} \mathrm{Sr}\right)+A_{\text {res }}\left({ }^{85} \mathrm{Sr}\right)}\right\} \times 100 \%, \\
& \Delta^{90} \mathrm{Sr}=\left\{\frac{A_{\text {sol }}\left({ }^{90} \mathrm{Sr}\right)}{A_{\text {sol }}\left({ }^{90} \mathrm{Sr}\right)+A_{\text {res }}\left({ }^{90} \mathrm{Sr}\right)}\right\} \times 100 \% .
\end{aligned}
$$

These percentages were used to calculate the fraction of undissolved fuel particles, estimated as

$$
\Delta \mathrm{FP}=\left[1-\frac{\Delta^{90} \mathrm{Sr}}{\Delta^{85} \mathrm{Sr}}\right] .
$$

For samples with a low ${ }^{90} \mathrm{Sr}:{ }^{154} \mathrm{Eu}$ ratio, it had previously been shown that leached ${ }^{90} \mathrm{Sr}$ had been removed from the 0 to $30 \mathrm{~cm}$ layer (Kashparov et al., 1999). This migration was particularly significant for sandy soils with very low humus content. Here, for such samples, the total estimated ${ }^{90} \mathrm{Sr}$ content was used to assess the fraction of undissolved fuel particles rather than $A_{\text {res }}\left({ }^{90} \mathrm{Sr}\right)$. The total ${ }^{90} \mathrm{Sr}$ content was derived from the vertical distribution of ${ }^{90} \mathrm{Sr}$ and ${ }^{154} \mathrm{Eu}$ activity. From estimates of initial activity concentrations in the fuel the ${ }^{90} \mathrm{Sr}:{ }^{154} \mathrm{Eu}$ ratio in 1996 of 56 would be expected (see discussion of predicted activity levels in fuel presented below).

The data contain a limited number of negative values which are the consequence of a low percentage of ${ }^{90} \mathrm{Sr}$ in the exchangeable form and a high associated error. Users of the data should assume these values to be zero.

\subsection{Survey of the Ivankov district}

A total of 3389 sampling points were identified for survey in 2014 , using a $1 \mathrm{~km}$ grid placed over the Ivankov district and surrounding $3 \mathrm{~km}$ (Fig. 3) (Kashparov et al., 2014). The coordinates of the sampling sites were determined by means of a GPS receiver (Garmin, GPSMap 78s) using the WGS-84 (world) system with the accuracy of $10 \mathrm{~m}$ or less.

Measurements of ambient equivalent dose rate (hereafter referred to as dose rate) were carried out at heights of 1 and $0.1 \mathrm{~m}$ above ground surface at $1 \mathrm{~km}$ intervals using this grid. Equivalent dose was measured using certified gamma-betairradiation dosimeters (RKS-01, Stora-TU, Ukraine). The measurement range of the dosimeters was approximately 0.1 to $1000 \mu \mathrm{Sv} \mathrm{h}^{-1}$ and the time taken to obtain a statistically reliable estimate was approximately $20 \mathrm{~s}$. Seven of the sites selected for survey were inaccessible; however, the locations have been left in the data for completeness.

An estimation of "zero background" for the dosimeters was made by taking measurements over a frozen water body in the centre of the Ivankov district. The contribution of gamma irradiation from natural and anthropogenic radionuclides was seen to be negligible and hence the readings were the sum of cosmic radiation and the detectors' own background (Kashparov et al., 2014). The background dose rates of the devices themselves were determined in the laboratory by taking measurements within a lead-shielded $(10 \mathrm{~cm}$ thick) area. The background dose rate of the detectors was estimated to be $0.05 \mu \mathrm{Sv} \mathrm{h}^{-1}$ and the zero background determined over the frozen lake was $0.08 \mu \mathrm{Sv} \mathrm{h}^{-1}$. Therefore, the contribution of cosmic radiation in the study area can be estimated to be approximately $0.03 \mu \mathrm{Sv} \mathrm{h}^{-1}$. Contributions from cosmic and instrument background were subtracted from measured values reported in the dataset.

A total of 547 soil samples were collected. Sampling locations were every third dose rate measurement point apart from within settlements where soils were sampled at every measurement point. Sample sites were selected that were undisturbed, relatively flat and with consistent vegetation cover, as well as where dose rate estimates did not vary by more than $30 \%$. Samples were taken at a distance from the nearest buildings or trees which equated to 2 times the height of the buildings or trees. The exception was for samples collected from forest or scrubland where the sample site was positioned equidistantly from the nearest trees or shrubs. Sampling points were located no closer than $20 \mathrm{~m}$ to roads or places where accumulation or wash-off of radioactive contamination was possible.

The envelope method was used to collect soil samples using a $37 \mathrm{~mm}$ corer down to a depth of not less than $20 \mathrm{~cm}$. The mass was not less than $3 \mathrm{~kg}$ for the composite sample.

Soil samples were oven dried at $105^{\circ} \mathrm{C}$ to constant weight, homogenised and sieved through a $1 \mathrm{~mm}$ sieve. Subsamples of 100 to $150 \mathrm{~g}$ were taken for ${ }^{90} \mathrm{Sr}$ analysis and for gamma analysis a $1 \mathrm{~L}$ Marinelli container was filled.

The approach used to determine ${ }^{90} \mathrm{Sr}$ activity concentration in soil samples was based on the standard ISO 18589-5:2009 (International Organization for Standardization, 2009). Strontium-90 activity was estimated through measurement of its daughter product, ${ }^{90} \mathrm{Y}$. The radiochemical preparation involved digestion of the ashed sample in $8 \mathrm{M} \mathrm{HNO}_{3}$ followed by oxalate precipitation. Strontium was purified using ammonia and saturated sodium carbonate solution. The resultant strontium carbonate was dissolved in $2.5 \mathrm{M} \mathrm{HNO}_{3}$; Y carrier was added and stored for 2 weeks such that ${ }^{90} \mathrm{Y}$ reached equilibrium. Yttrium was then precipitated as oxalate and ${ }^{90} \mathrm{Y}$ was measured using a beta spectrometer (SEB-70, AKP, Ukraine). The radiochemical separation yield was calculated using carriers such as stable $\mathrm{Sr}$ and $\mathrm{Y}$ measured using atomic absorption spectroscopy (Varian). Gamma analyses were conducted as described above. Quality assurance of radioanalytical procedures was based on ISO/IEC 17025 standards. The laboratory regularly participated in international and national proficiency tests (e.g. International Atomic Energy Agency). 

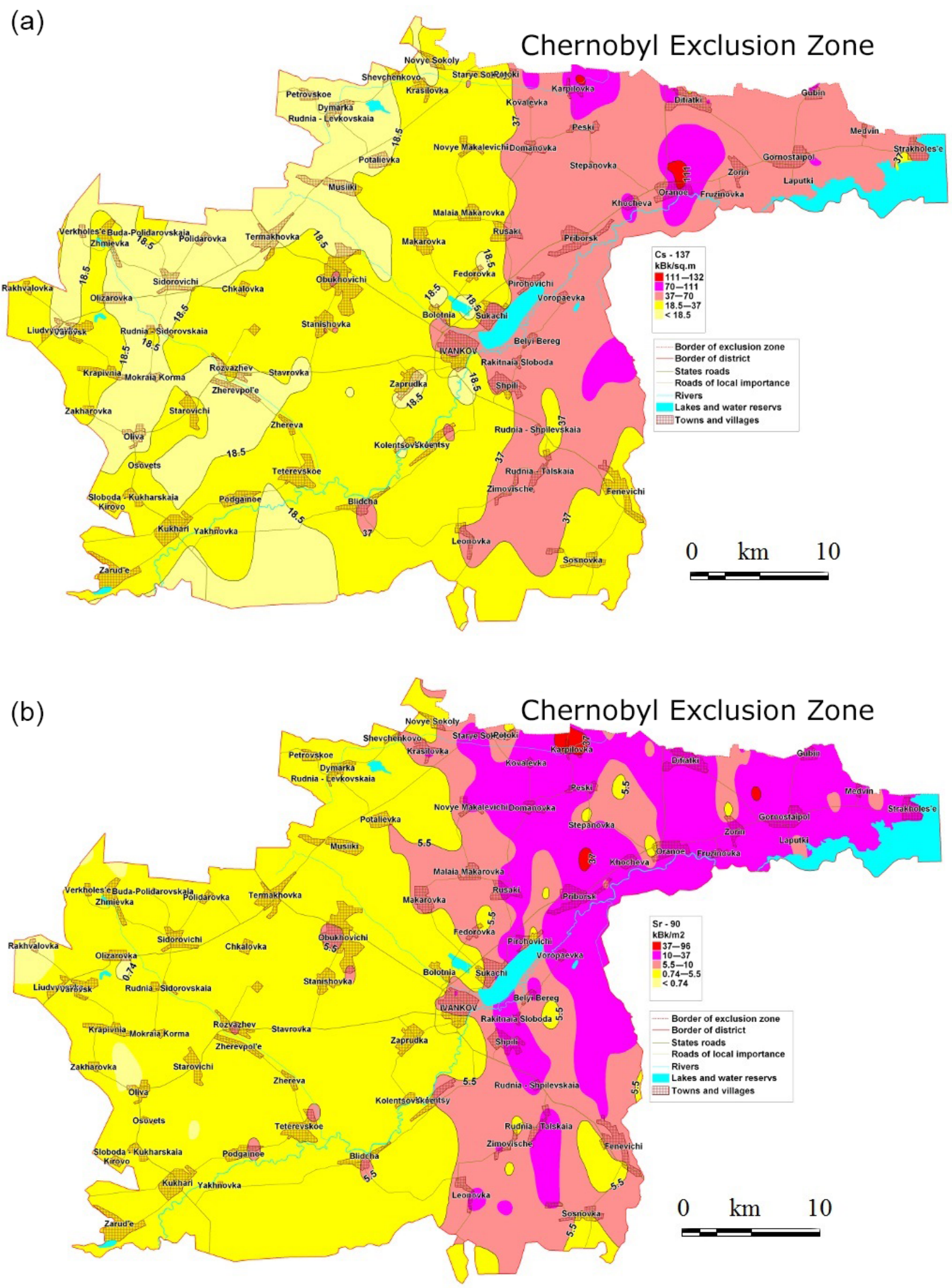

Figure 4. Spatial variation in ${ }^{137} \mathrm{Cs}(\mathbf{a})$ and ${ }^{90} \mathrm{Sr}(\mathbf{b})$ soil concentrations $\left(\mathrm{kBq} \mathrm{m}^{-2}\right)$ in the Ivankov district in 2014. 


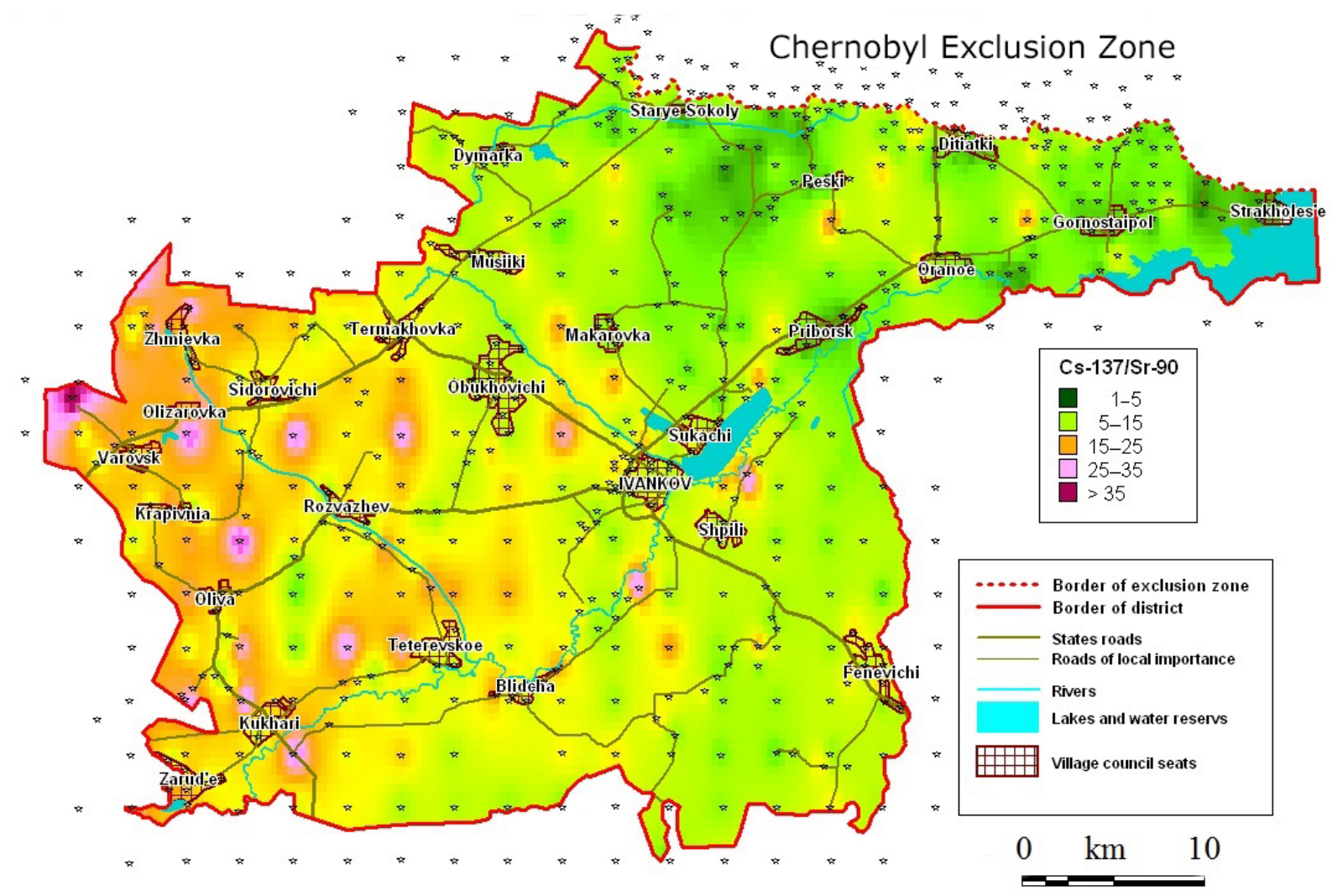

Figure 5. Spatial variation in ${ }^{137} \mathrm{Cs}:{ }^{90} \mathrm{Sr}$ ratio in the Ivankov district (sampling points are shown as black stars).

The dataset reports activity concentrations for the natural radionuclides ${ }^{40} \mathrm{~K},{ }^{226} \mathrm{Ra}$ and ${ }^{232} \mathrm{Th}$ in addition to ${ }^{137} \mathrm{Cs}$ and ${ }^{90} \mathrm{Sr}$. The mean activity concentrations for these radionuclides were $140 \mathrm{~Bq} \mathrm{~kg}^{-1}{ }^{40} \mathrm{~K}, 12 \mathrm{~Bq} \mathrm{~kg}^{-1}{ }^{226} \mathrm{Ra}$ and $10 \mathrm{~Bq} \mathrm{~kg}^{-1}{ }^{232} \mathrm{Th}$. Natural background radionuclides are sometimes cited as being relatively low in the CEZ (Møller and Mousseau, 2011) though there are few data in the international literature. On the basis of soil types we could expect the CEZ to have similar natural radionuclide activity concentrations in soils to the Ivankov district. These activity concentrations do appear to be relatively low compared to average values for e.g. the UK (Beresford et al., 2008).

Caesium-137 activity concentrations in the Ivankov district soils range from 6 to $390 \mathrm{~Bq} \mathrm{~kg}^{-1}$ dry matter. Strontium90 concentrations range from 1 to $160 \mathrm{~Bq} \mathrm{~kg}^{-1}$ dry matter. These compare to anticipated global fallout values of approximately $4 \mathrm{~Bq} \mathrm{~kg}^{-1}{ }^{137} \mathrm{Cs}$ and $1 \mathrm{~Bq} \mathrm{~kg}^{-1}{ }^{90} \mathrm{Sr}$. Activity concentrations of both ${ }^{137} \mathrm{Cs}$ and ${ }^{90} \mathrm{Sr}$ were highest in the east of the Ivankov district (Fig. 4). On an aerial basis ${ }^{137} \mathrm{Cs}$ ranged from 2 to $140 \mathrm{kBq} \mathrm{m}^{-2}$ and ${ }^{90} \mathrm{Sr}<1$ to $60 \mathrm{kBq} \mathrm{m}^{-2}$. The ${ }^{137} \mathrm{Cs}:{ }^{90} \mathrm{Sr}$ ratio increased to the west and south of the Ivankov district with distance from the ChNPP (Fig. 5).

Dose rates at $1 \mathrm{~m}$ across the Ivankov district ranged from 0.1 to $0.24 \mu \mathrm{Svh}^{-1}$. From measurements of natural radionuclides in soil and using conversion coefficients by
UNSCEAR $(1977,1988)$, a dose rate of 0.01 to $0.07 \mu \mathrm{Sv} \mathrm{h}^{-1}$ was estimated. There was a tendency for dose rates to increase with increasing ${ }^{137} \mathrm{Cs}$ activity concentration in soils although correlation was poor $\left(R^{2}=0.11\right.$ for measurements at $1 \mathrm{~m})$.

\section{Data availability}

All samples after gamma-spectrometry measurements are stored at NUBIP and can be made available on request.

The data described here have a digital object identifier (doi:10.5285/782ec845-2135-4698-8881-b38823e533bf) and are freely available for registered users from the NERC Environmental Information Data Centre (http://eidc.ceh.ac.uk/) under the terms of the Open Government Licence.

The data must be fully referenced for every use as follows: Kashparov, V., Levchuk, S., Zhurba, M., Protsak, V., Khomutinin, Y., Beresford, N. A., and Chaplow, J. S. (2017): Spatial datasets of radionuclide contamination in the Ukrainian Chernobyl Exclusion Zone. NERC-Environmental Information Data Centre, doi:10.5285/782ec845-2135-4698-8881b38823e533bf. Supporting documentation to aid in the reuse of these data are also available from the EIDC. 
Competing interests. The authors declare that they have no conflict of interest.

Acknowledgements. Funding for preparing this paper and the accompanying dataset (Kashparov et al., 2017) was provided by the EU COMET project (http: //www.radioecology-exchange.org/content/comet) and TREE (http://www.ceh.ac.uk/tree) project funded by NERC, the Environment Agency and Radioactive Waste Management Ltd under the RATE programme.

Edited by: David Carlson

Reviewed by: Andrey Zaitsev and one anonymous referee

\section{References}

Aronov, V. I.: Methods of creation of maps of geological and geophysical characteristics and application of geometry for mapping of oil and gas deposits using computers, Book Company "Nedra", Moscow, Russia, 1990 (in Russian).

Balashazy, I., Hofmann, W., and Martonen, T. B.: A model of particle deposition at airway bifurcations, J. Aerosol Med., 1, 190191, 1988.

Barnett, C. and Welch, S.: Thirty years after the Chernobyl accident: what do we know about the effects of radiation on the environment?, COMET project, European Commission, available at: http://www.radioecology-exchange.org/sites/www. radioecology-exchange.org/files/files/Deliverable_56_COMET_ workshop_4_final.pdf (last access 13 June 2017), 2016.

Beaugelin-Seiller, K., Garnier-Laplace, J., and Beresford, N. A.: Estimating radiological exposure of wildlife in the field, J. Environ. Radioactiv., submitted, 2018.

Begichev, S. N., Borovoy, A. A., Burlakov, E. V., Havrilov, S. L., Dovbenko, A. A., Levina, L. A., Markushev, D. M., Marchenko, A. E., Stroganov, A. A., and Tataurov A. K.: Preprint IAE5268/3: Reactor Fuel of Unit 4 of the Chernobyl NPP (a brief handbook), Moscow, Publisher Kurchatov Institute of Atomic Energy, 21 pp., 1990 (in Russian).

Beresford, N. A. and Copplestone, D.: Effects of ionizing radiation on wildlife: what knowledge have we gained between the Chernobyl and Fukushima accidents?, Integr. Environ. Asses., 7, 371-373, soi:10.1002/ieam.238, 2011.

Beresford, N. A., Barnett, C. L., Jones, D. G., Wood, M. D., Appleton, J. D., Breward, N., and Copplestone, D.: Background exposure rates of terrestrial wildlife in England and Wales, J. Environ. Radioactiv., 99, 1430-1439, https://doi.org/10.1016/j.jenvrad.2008.03.003, 2008.

Beresford, N. A., Barnett, C. L., Howard, B. J., Howard, D. C., Wells, C., Tyler, A. N., Bradley, S., and Copplestone, D.: Observations of Fukushima fallout in Great Britain, J. Environ. Radioactiv., 114, 48-53, https://doi.org/10.1016/j.jenvrad.2011.12.008, 2012a.

Beresford, N. A., Adam-Guillermin, C., Bonzom, J.-M., GarnierLaplace, J., Hinton, T., Lecomte, C., Copplestone, D., Della Vedova, C., and Ritz, C.: Response to authors' reply regarding "Abundance of birds in Fukushima as judged from Cher- nobyl” by Møller et al., 2012, Environ. Pollut., 169, 139-140, https://doi.org/10.1016/j.envpol.2012.05.013, 2012b.

Beresford, N. A., Fesenko, S., Konoplev, A., Smith, J. T., Skuterud, L., and Voigt, G.: Thirty years after the Chernobyl accident, J. Environ. Radioactiv., 157, 38-40, https://doi.org/10.1016/j.jenvrad.2016.01.023, 2016.

Chaplow, J. S., Beresford, N. A., and Barnett, C. L.: Post Chernobyl surveys of radiocaesium in soil, vegetation, wildlife and fungi in Great Britain, NERC Environmental Information Data Centre, https://doi.org/10.5285/d0a6a8bf-68f0-4935-8b434e597c3bf251, 2015a.

Chaplow, J. S., Beresford, N. A., and Barnett, C. L.: PostChernobyl surveys of radiocaesium in soil, vegetation, wildlife and fungi in Great Britain, Earth Syst. Sci. Data, 7, 215-221, https://doi.org/10.5194/essd-7-215-2015, 2015b.

Dabrowska, M., Jaracz, P., Jastrzebski, J., Kaczanowski, J., Mirowski, S., Osuch, S., Piasecki, E., Pienkowski, L., Szeflinska, G., Szeflinski, Z., Tropilo, J., and Wilhlemi, Z.: Isotopic composition of hot particles collected in North-East Poland, International Workshop on Hot Particles in the Chernobyl Fallout, Theuern, Germany, 28-29 October, 1987.

Evangeliou, N., Hamburger, T., Talerko, N., Zibtsev, S., Bondar, Y., Stohl, A., Balkanski, Y., Mousseau, T. A., and Møller A. P.: Reconstructing the Chernobyl Nuclear Power Plant (CNPP) accident 30 years after, A unique database of air concentration and deposition measurements over Europe, Environ. Pollut., 216, 408-418, 2016.

Derzhavin, L. M., Samohvalov, S. G., Sokolov, N. V., Prizhukov, V. G., Shaymukhametova, A. A., Yerinov, A. L., Luchkina, L. E., Konkina, V. L., Pankova, N. G., Vasilevskaya, N. V., Pleshkova, A.P., Yakovleva, A. A., Gruzdeva, T. S., Chebotareva, N. A., Molkanova, L. I., Soboleva, O. V., and Kondratieva, G. K.: GOST 26423-85, Soil, Methods for determination of specific electric conductivity, $\mathrm{pH}$ and dense residue of aqueous extract, Ministry of Agriculture of the USSR, available at: http://docs.cntd.ru/ document/gost-26423-85 (last access: 19 February 2018), 1985a.

Derzhavin, L. M., Samohvalov, S. G., Sokolov, N. V, Prizhukova, V. G., Shaymukhametova, A. A., Molkanova, L. I., Chukova, T. V., Belyanina, E. N., Mayortz, G. A., Mezhova, N. P., Erinov, A. E., Arsenyeva, M. N., Gruzdeva, T. S., Vasilevskaya, N. V., Sukhareva, V. N., Pleshkova, A. P., Yakovleva, A. A., and Orlov, A. N.: GOST 26483-85, Soil, Preparation of salt extract and determination of its $\mathrm{pH}$ by the CINAO method, Ministry of Agriculture of the USSR, available at: http://docs.cntd.ru/document/ gost-26483-85 (last access: 19 February 2018), 1985 b.

Derzhavin, L. M., Samohvalov, S. G., Sokolov, N. V, Prizhukova, V. G., Shaymukhametova, A. A., Molkanova, L. I., Chukova, T. V., Belyanina, E. N., Mayortz, G. A., Mezhova, N. P., Erinov, A. E., Arsenyeva, M. N., Gruzdeva, T. S., Vasilevskaya, N. V., Sukhareva, V. N., Pleshkova, A. P., Yakovleva, A. A., and Orlov, A. N.: GOST 26487-85, Soils, Determination of exchangeable calcium and exchangeable (mobile) magnesium by CINAO methods, Ministry of Agriculture of the USSR, available at: http://docs.cntd.ru/document/gost-26487-85 (last access: 19 February 2018), 1985c.

Derzhavin, L. M., Samohvalov, S. G., Sokolov, N. V., Orlov, A. N., Khabarov, K. A., Prizhukov, V. G., and Privalenkov S. Y.: GOST 26213-91, Soil, Methods for the determination of organic matter, Committee for Standardization and Metrology of the 
USSR, available at: http://docs.cntd.ru/document/gost-26213-91 (last access: 19 February 2018), 1991a.

Derzhavin, L. M., Samohvalov, S. G., Sokolov, N. V., Orlov, A. N., Khabarov, K. A., Sukharev, V. N., Fedotov, M. I., and Sokolov, Y. V.: GOST 26207-91, Soils, Determination of mobile compounds of phosphorus and potassium by Kirsanov method modified by CINAO, Committee for Standardization and Metrology of the USSR, available at: http://docs.cntd.ru/document/gost-26207-91 (last access: 19 February 2018), 1991 b.

Derzhavin, L. M., Samohvalov, S. G., Sokolov, N. V., Orlov, A. N., Khabarov, K. A., Vasilevskaya, N. V., and Erinov, A. E.: GOST 26212-91, Soils, Determination of hydrolytic acidity by Kappen method modified by CINAO, Committee for Standardization and Metrology of the USSR, available at: http://docs.cntd.ru/ document/gost-26212-91 (last access: 19 February 2018), 1991c.

Derzhavin, L. M., Samohvalov, S. G., Sokolov, N. V., Orlov, A. N., , Sukharev, V. N., Fedotov, M. I., and Sokolov, V. V.: GOST 26204-91, Soils, Determination of mobile compounds of phosphorus and potassium by Chiricov method modified by CINAO, Committee for Standardization and Metrology of the USSR, available at: http://docs.cntd.ru/document/gost-26204-91 (last access: 21 February 2018), 1991d.

Hinton, T. G., Garnier-Laplace, J., Vandenhove, H., Dowdall, M., Adam-Guillermin, C., Alonzo, F., Barnett, C., Beaugelin-Seiller, K., Beresford, N. A., Bradshaw, C., Brown, J., Eyrolle, F., Fevrier, L., Gariel, J.-C., Gilbin, R., Hertel-Aas, T., Horemans, N., Howard, B. J., Ikäheimonen, T., Mora, J. C., Oughton, D., Real, A., Salbu, B., Simon-Cornu, M., Steiner, M., Sweeck, L., and Vives i Batlle, J.: An invitation to contribute to a strategic research agenda in radioecology, Environ. Radioactivity, 115, 7382, https://doi.org/10.1016/j.jenvrad.2012.07.011, 2013.

International Organization for Standardization: Measurement of radioactivity in the environment - Soil - Part 5: Measurement of strontium 90, ISO 18589-5:2009, available at: https://www.iso. org/standard/40877.html (last access 17 May 2017), 2013.

Ivanov, Y. A., Lewyckyj, N., Levchuk, S. E., Prister, B. S., Firsakova, S. K., Arkhipov, N. P., Arkhipov, A. N., Kruglov, S. V., Alexakhin, R. M., Sandalls, J., and Askbrant, S.: Migration of ${ }^{137} \mathrm{Cs}$ and ${ }^{90} \mathrm{Sr}$ from Chernobyl fallout in Ukrainian, Belarussian and Russian soils, J. Environ. Radioactiv., 35, 1-21, 1997.

Kashparov, V. A.: Hot Particles at Chernobyl, Environ. Sci. Pollut. R., 10, 21-30, 2003.

Kashparov, V. A., Ivanov, Y. A., Zvarich, S. I., Protsak, V. P., Khomutinin, Y. V., Kurepin, A. D., and Pazukhin, E. M.: Formation of Hot Particles During the Chernobyl Nuclear Power Plant Accident, Nucl. Technol., 114, 246-253, 1996.

Kashparov, V. A., Ivanov, Y. A., Protsak, V. P., Khomucinin, Y. V., Yoschenko, V. I., and Pazukhin, E. M.: Assessment of the maximal temperature and of the duration of annealing of Chernobyl fuel particles during the accident, Radiokhimiya (Radiochemistry) 39, 66-70, 1997 (in Russian).

Kashparov, V. A., Oughton, D. H., Zvarich, S. I., Protsak, V. P., and Levchuk, S. E.: Kinetics of fuel particle weathering and ${ }^{90} \mathrm{Sr}$ mobility in the Chernobyl 30-km exclusion zone, Health Phys., 76, 251-259, 1999.

Kashparov, V. A., Lundin, S. M., Khomutinin, Y. V., Kaminsky, S. P., Levtchuk, S. E., Protsak, V. P., Kadygrib, A. M., Zvarich, S. I., Yoschenko, V. I., and Tschiersch, J.: Soil contamination with
${ }^{90} \mathrm{Sr}$ in the near zone of the Chernobyl accident, J. Environ. Radioactiv., 56, 285-298, 2001.

Kashparov, V. A., Ahamdach, N., Zvarich, S. I., Yoschenko, V. I., Maloshtan, I. M., and Dewiere, L.: Kinetics of dissolution of Chernobyl fuel particles in soil in natural conditions, J. Environ. Radioact., 72, 335-353, https://doi.org/10.1016/j.jenvrad.2003.08.002, 2004.

Kashparov, V. A.: Assessment of ecological risk caused by the longliving radionuclides in the environment, in: Ecotoxicology, Ecological Risk Assessment and Multiple Stressors, edited by: Arapis, G., Goncharova, N., and Baveye, P., Nato Sci. Peace Secur., 6, 155-164, 2006.

Kashparov, V. A., Levchuk, S., Protsak, V., Khomutinin, Yu, Maloshtan, I., Yoshenko, L., Otreshko, L., Pavlushenko, N., Kadygryb, A., Glukhovsky, A., Landshyn, V., Korol, V., and Lyubatchevskii, S. V.: Mapping the contamination of Ivankiv district territory with radionuclides Final report November 2013September 2014 on the studies carried out by UIAR within the frameworks of contract No. 2013-04 from 19 November 2013, 2014.

Kashparov, V., Levchuk, S., Zhurba, M., Protsak, V., Khomutinin, Y., Beresford, N. A., and Chaplow, J. S.: Spatial datasets of radionuclide contamination in the Ukrainian Chernobyl Exclusion Zone, NERC-Environmental Information Data Centre, https://doi.org/10.5285/782ec845-2135-46988881-b38823e533bf, 2017.

Kerekes, A., Falk, R., and Suomela, J.: Analysis of hot particles collected in Sweden after the Chernobyl accident, Statens Stralskyddinstitut, SSI-rapport 91-02, 1991.

Khomutinin, Y. V., Kashparov, V. A., and Zhebrovska, K. I.: Sampling optimisation when radioecological monitoring, Book publisher "VIPOL" Kiev, Ukraine, available at: http://www.uiar.org. ua/Eng/7.pdf (last access: 19 February 2018), 2004.

Kuriny, V. D., Ivanov, Y. A., Kashparov, V. A., Loschilov, N. A., Protsak, V. P., Yudin, E. B., Zhurba, M. A., and Parshakov, A. E.: Particle associated Chernobyl fall-out in the local and intermediate zones, Ann. Nucl. Energy, 20, 415-420, 1993.

Loshchilov, N. A., Kashparov, V. A., Yudin, Y. B., Protsak, V. P., Zhurba, M. A., and Parshakov, A. E.: Experimental assessment of radioactive fallout from the Chernobyl accident, Sicurezza e Protezione, 25-26, 46-49, 1991.

Mandjoukov, I. G., Burin, K., Mandjoukova, B., Vapirev, E. I., and Tsacheva T. S.: Spectrometry and visualization of "standard" hot particles from the Chernobyl accident, Radiat. Prot. Dosim., 40, 235-244, 1992.

Møller, A. P. and Mousseau, T. A.: Efficiency of bio-indicators for low-level radiation under field conditions, Ecol. Indicators, 11, 424-430, 2011.

Osuch, S., Dabrovska, M., Jaracz, P., Kaczanowski, J., Le Van Khoi., Mirowski, S., Piasecki, E., Szeflinska, G., Szeflinski, Z., Tropilo, J., Wilheimi, Z., Jastrzebski, J., and Pienkowski, L.: Isotopic composition of high-activity particles released in the Chernobyl accident, Health Phys., 57, 707-716, 1989.

Oughton, D. H., Salbu, B., Brand, T. L., Day, J. P., and Aarkrog, A.: Under-determination of strontium-90 in soils containing particles of irradiated uranium oxide fuel, Analyst, 118, 1101-1105, 1993.

Pavlotskaya, F. I.: Main principles of radiochemical analysis of environmental objects and methods of measurements of strontium 
and transuranium elements radionuclides, J. Anal. Chem., 52, 126-143, 1997 (in Russian).

Salbu, B., Krekling, T., Oughton, D. H., Ostby, G., Kashparov, V. A., Brand, T. L., and Day, J. P.: Hot particles in accidental releases from Chernobyl and Windscale nuclear installations, Analyst, 119, 125-130, 1994.

Schubert, P. and Behrend, U.: Investigations of radioactive particles from the Chernobyl fall-out, Radiochim. Acta, 41, 149-155, 1987.

Shestopalov, V. M., Kashparov, V. A., and Ivanov, Y. A.: Radionuclide Migration into the Geological Environment and Biota Accident, Environ. Sci. Pollut. R., 10, 39-47, 2003.

Smith, J. T. and Beresford, N. A.: Radioactive fallout and environmental transfers, in: Chernobyl - catastrophe and consequences, edited by: Smith, J. T. and Beresford, N. A., Chichester, Praxis Publishing/Springer, 35-80, 2005.

SOU 74.14-37-424:2006. The quality of the soil, Determine the density of contamination of agricultural land anthropogenic radionuclides, Ministry of Agrarian Policy and Food of Ukraine, 2006 (in Ukrainian).

Steiner, M., Willrodt, C., Wichterey, K., Ikäheimonen, T., Ioshchenko, V., Hutri, K. L., Muikku, M., Outola, I., Beresford, N. A., Bradshaw, C., Dowdall, M., Eyrolle-Boyer, F., Guillevic, J., Hinton, T., Howard, B. J., Liland, A., Michalik, B., Mora, J. C., Oughton, D., Real, A., Robles, B., Salbu, B., Stark, K., and Sweeck, L.: Observatories for Radioecological Research - Description, STAR project, European Commission, available at: http://www.radioecology-exchange.org/sites/www. radioecology-exchange.org/files/STAR_Deliverable-2.3.pdf (last access: 3 June 2017), 2013.
Stolbovoi, V.: Soils of Russia: Correlated with the revised legend of the FAO soil map of the world and world reference base for soil resources, IIASA Research Report, IIASA, Laxenburg, Austria: RR-00-013, available at: http://pure.iiasa.ac.at/6111 (last access: 10 July 2017), 2000.

UIAR: The map of the 30-km Chernobyl zone terrestrial density of contamination with strontium-90 (in 1997), UIAR, Kyiv, Ukraine, 1998.

United Nations Scientific Committee on the Effects of Atomic Radiation (UNSCEAR): UNSCEAR 1977 Report, Sources and effects of ionizing radiation, available at: http://www.unscear.org/ unscear/en/publications/1977.html (last access: 7 June 2017), 1977.

United Nations Scientific Committee on the Effects of Atomic Radiation (UNSCEAR): UNSCEAR 1988 Report, Sources, effects and risks of ionizing radiation, available at: http://www.unscear. org/unscear/en/publications/1988.html (last access: June 2017), 1988.

United States Nuclear Regulatory Commmission (USNRC): Uranium Enrichment, available at: https://www.nrc.gov/materials/ fuel-cycle-fac/ur-enrichment.html, last access: 12 June 2017.

Zhurba, M., Kashparov, V., Ahamdach, N., Salbu, B., Yoschenko, V., and Levchuk, S.: The "hot particles" data base. Radioactive Particles in the Environment, NATO Science for Peace and Security Series C: Environmental Security, edited by: Oughton, D. and Kashparov, V., Springer, the Netherlands 187195 https://doi.org/10.1007/978-90-481-2949-2_12, 2009. 